Sistemik Lupus Eritematozlu Hastalarda Böbrek Tutulumu ve

Ortalama Trombosit Hacmi

\title{
Mean Platelet Volume and Renal Involvement in Patients with Systemic Lupus Erythematosus
}

Gökhan Sargın, Taşkın Şentürk

Adnan Menderes Üniversitesi Tıp Fakültesi, Romatoloji Bilim Dalı, Aydın, Türkiye.

\section{$\ddot{O} Z$}

Amaç: Amacımız, sistemik lupus eritematozuslu (SLE) hastalarda ortalama trombosit hacmi (MPV) ile renal tutulum arasındaki ilişkiyi belirlemektir. Ayrıca renal tutulumlu SLE hastalarında eritrosit sedimantasyon hizı (ESH), C-reaktif protein (CRP), kompleman bileșen 3 (C3), C4 ve hastallk aktivitesini başlangıçta ve tedavinin 6. ayında değerlendirmeyi amaçladık.

Gereç ve Yöntemler: Çalışmaya SLE tanısı almış 85 hasta (4 erkek, 81 kadın, ortalama yaş 39,5 10,5 yll) alındı. Yaş, cinsiyet, MPV, CRP, ESH, C3, C4 ve SLE hastallk aktivite indeksi (SLEDAI) değerlendirildi. Veriler KolmogorovSmirnov, Mann-Whitney, Wilcoxon testi ve Spearman korelasyonu ile değerlendirildi.

Bulgular: MPV düzeyi, nefriti olmayan hastalarda nefriti olan hastalara göre daha yüksekti. Her iki grup arasinda MPV açısından anlaml farklılık yoktu. Böbrek tutulumu olan ve böbrek tutulumu olmayan SLE hastalarında MPV ile hastallk aktivitesi arasinda korelasyon saptand (sirasiyla, $r=-0,396$, $p=0,04, r=-0,262, p=0,03$ ).

Sonuç: Böbrek tutulum olan ve olmayan lupus hastalarında hastallk aktivitesi ile MPV negatif korelasyon göstermektedir. $M P V, \quad S L E ' l i$ hastalarda hastalı aktivitesini ve organ tutulumunu değerlendirmede yardımcı olabilir. Yinede, bu konuyla ilgili uzun dönem sonuçları hakkında bilgiler sınırlıdır.

Anahtar Kelimeler: sistemik lupus eritematozus, ortalama trombosit hacmi, böbrek tutulumu, sistemik lupus eritematozus hastalık aktivite indeksi

\begin{abstract}
INTRODUCTION: Our aim is to determine the relationship between mean platelet volume (MPV) and renal involvement in patients with systemic lupus erythematosus (SLE). We also aimed to evaluate erythrocyte sedimentation rate (ESR), $C$ reactive protein (CRP), complement component $3(C 3), C 4$, and disease activity at the baseline and 6th months of treatment in SLE patients with renal involvement.
\end{abstract}

METHODS: A total of 85 SLE patients (4 male, 81 female, with the mean age of $39,5 \pm 10,5$ years) who had been diagnosed with SLE were enrolled in the study. Age, gender, $M P V, C R P, E S R, C 3, C 4$, and SLE Disease Activity Index (SLEDAI) were evaluated. The data were assessed with Kolmogorov-Smirnov, Mann-Whitney, Wilcoxon test, and Spearman correlation.

RESULTS: The levels of MPV were higher in patients without nephritis compared to patients with nephritis. There was no significant difference in MPV between both groups. We found a correlation between MPV and disease activity for SLE patients with renal involvement and without renal involvement ( $r=-$ $0,396, p=0.04, r=-0.278, p=0.03$, respectively).

DISCUSSION and CONCLUSION: MPV is negatively correlated with disease activity in lupus patients with renal involvement and without renal involvement. MPV may be helpful to assess disease activity and organ-involvement in patients with SLE. the knowledge about long-term results about this topic is limited.

Keywords: systemic lupus erythematosus, mean platelet volume, renal involvement, systemic lupus erythematosus disease activity index

İletişim / Correspondence:

Dr. Gökhan Sargın

Adnan Menderes Üniversitesi Tip Fakültesi, Romatoloji Bilim Dall, Aydın, Türkiye.

E-mail: gokhan_sargin@hotmail.com

Başvuru Tarihi: 09.03.2019

Kabul Tarihi: 27.04.2019 


\section{INTRODUCTION}

Systemic lupus erythematosus (SLE) is a chronic inflammatory autoimmune multisystem disease with a variable spectrum of clinical, laboratory features, and the presence of immunological abnormalities and autoantibodies (1). It is characterized by photosensitivity, arthritis, mucocutaneous manifestations, serositis, and various systemic involvement including cardiac, pulmonary, neurological, and renal (2). Autoantibodies contribute to tissue and organ damage in SLE which develops with the effect of genetic background and environmental factors $(1,2)$.

SLE patients have many symptoms and clinical signs of organ involvement, and almost every organ and system may be affected. Renal involvement occurs clinically up to half of the patients and most of the remaining patients have subclinical renal involvement $(3,4)$. According to the International Society of Nephrology/Renal Pathology Society classification criteria, it is classified as minimal mesangial lupus nephritis (LN), mesangial proliferative $\mathrm{LN}$, focal $\mathrm{LN}$, diffuse $\mathrm{LN}$, membranous LN, and advanced sclerosing LN (5). Each of them has their own characteristics and clinical findings. Kidney function tests, urine analysis, proteinuria, and renal biopsy are useful to define renal involvement in SLE.

It is recommended to monitor blood pressure, urinalysis, protein/creatinine ratio, serum creatinine, anti-double stranded DNA (anti-dsDNA), complement component 3 (C3), and complement component 4 (C4) levels with recommended intervals in lupus nephritis. Serum C3, C4, antidsDNA are frequently used in practice to assess the activation of lupus nephritis (6). European Consensus Lupus Activity Measurements, and British Isles Lupus Assessment Group, and SLE Disease Activity Index (SLEDAI) are used to determine disease activity of SLE (7). The indexes include parameters associated with renal involvement such as arterial blood pressure, hematuria, pyuria, urinary proteinuria/creatine ratio, urinary sediment, and 24-hour urinary proteinuria.

The changes in mean platelet volume (MPV) levels were reported as an early sign of disease activation in pediatric lupus patients (8). Decreased level of MPV was reported in adult patients with active lupus and at remission period of SLE patients with renal involvement (9). However, the relevant data are still lacking about MPV and lupus nephritis.

Our aim is to determine the relationship between MPV and renal involvement in patients with SLE. Also, we evaluate erythrocyte sedimentation rate (ESR), C-reactive protein (CRP), C3, C4, and disease activity at the baseline and 6th months of treatment in SLE patients with renal involvement.

\section{MATERIAL AND METHODS}

A total of 85 patients ( 4 male, 81 female, with the mean age of $39,5 \pm 10,5$ years) who had been diagnosed with SLE were enrolled in the study. We excluded the patients with the history of any rheumatic disease other than SLE, solid/hematological malignancies, acute/chronic infections, heart or thyroid disease, thrombocytopenia, congenital/acquired platelet dysfunctions, the use of anti-coagulant, anti-platelet drugs, and age under 18 from the study. The study was performed in accordance with the guidelines of the Declaration of Helsinki and the ethical committee of our University approved the study (approval no: 2019/02).

Demographic data, clinical information, and laboratuary test results were obtained from the archive files. The diagnosis of SLE had been established on the basis of the Systemic Lupus International Collaborating Clinics classification criteria (10). Lupus nephritis was evaluated according to the International Society of Nephrology/Renal Pathology Society classification according to 6 stages: Class I-Minimal mesangial lupus nephritis, Class II-Mesangial proliferative lupus nephritis, Class III-Focal lupus nephritis, Class IV-Diffuse lupus nephritis, Class V-Membranous lupus nephritis, and Class VI-Advanced sclerotic lupus nephritis (5).

The following parameters were evaluated; age, gender, MPV, CRP, ESR, C3, C4, and disease activity index. Disease activity was evaluated by using SLEDAI (7). The MPV was calculated from complete blood count. Complete blood count were performed by the same hematology analyzer, Coulter 
Gene-S instrument (Beckman Coulter, California, USA) within one hour after collection of samples.

The data were specified as frequency, percentage, mean \pm standard deviation, and median (interquartile range). Kolmogorov-Smirnov test was used to determine the distribution of normality. MannWhitney test or was used to compare the differences between groups, and Wilcoxon test repeated measures. The linear correlation analyses was evaluated with Spearman or Pearson correlation. The results were assessed at $95 \%$ confidence interval and p-value of less than 0.05 was accepted as significant. The analysis of the data was carried out using the PASW for Windows version 17.0 (Statistical Package for Social Sciences Inc., Chicago, IL, USA).

\section{RESULTS}

Four of 85 patients were male and $95,3 \%$ of SLE patients were female with the mean age of $39,7 \pm 10,4$ years. The patients with SLE were divided into two groups: 27 SLE patients with renal involvement and 58 SLE patients without renal involvement.

The mean age of SLE patients with renal involvement was $37.3 \pm 12.1$ years and female/male ratio was 5.75 . The mean age was $40.6 \pm 9.6$ years in SLE patients without renal involvement. There was 7 SLE patients with Class 2 nephritis, 8 with Class 4 , 7 with Class 5, 1 for each Class 4+5, Class 6, and 3 for Class $3+5$. There was no statistically significant difference age between both groups. All of the patients with SLE were classified as an active disease at the diagnosis according to the SLEDAI. The mean level of disease activity was $10.6 \pm 6.2$. The demographic, clinical, and laboratory features of the patients with SLE included in the study are presented in Table 1.

There was a positive correlation between SLEDAI and sedimentation in all SLE patients $(r=0.371, p<0.01)$, with nephritis $(r=0.479, p=0.01)$, and without nephritis $(\mathrm{r}=0.268, \mathrm{p}=0.04)$. There was no correlation was found between SLEDAI and CRP.

\begin{tabular}{|c|c|}
\hline \multicolumn{2}{|c|}{ Total $(n=85)$} \\
\hline $\begin{array}{l}\text { Age (mean, } \\
\text { year) }\end{array}$ & $39.5 \pm 10.5$ \\
\hline $\begin{array}{c}\text { Gender } \\
\text { (male/female) }\end{array}$ & $4 / 81$ \\
\hline $\begin{array}{c}\text { Renal } \\
\text { involvement } \mathrm{n} \\
(\%)\end{array}$ & $27(\% 31.8)$ \\
\hline Class 2 & $7(\% 25.9)$ \\
\hline Class 4 & $8(\% 29.6)$ \\
\hline Class 5 & $7(\% 25.9)$ \\
\hline Class 6 & $1(\% 3.7)$ \\
\hline Class 3+5 & $3(\% 11.1)$ \\
\hline Class $4+5$ & $1(\% 3.7)$ \\
\hline SLEDAI & $10.6 \pm 6.2$ \\
\hline $\begin{array}{l}\text { Sedimantation } \\
(\mathrm{mm} / \mathrm{h})\end{array}$ & $36.0 \pm 22.4$ \\
\hline CRP (mg/dl) & $2.1(0.8-7.5)^{*}$ \\
\hline MPV (fL) & $10.2 \pm 1.1$ \\
\hline $\mathrm{C3}(\mathrm{g} / \mathrm{L})$ & $102.1 \pm 34.6$ \\
\hline C4 (g/L) & $22.3 \pm 13.8$ \\
\hline $\begin{array}{l}\text { median }(25-75 \mathrm{pe} \\
\text { rythematosus Dise } \\
\text { LPV: mean platele }\end{array}$ & $\begin{array}{l}\text { I: Systemic lupus } \\
x, \text { CRP: } C \text {-reactive protein, } \\
\text { plement }\end{array}$ \\
\hline
\end{tabular}

In lupus nephritis, C3 and C4 levels were $86.3 \pm 39.3$ and $16.8 \pm 12.4$, respectively. $\mathrm{C} 3$ and $\mathrm{C} 4$ levels were increased on the 6th months of treatment in patients with lupus nephritis. There was a significant difference for $\mathrm{C} 3$ and $\mathrm{C} 4$ in patients with lupus nephritis compared to patients without nephritis ( $\mathrm{p}=0.01, \mathrm{p}=0.007$, respectively). All patients with renal involvement received azathioprine or mycophenolate mofetil as maintenance treatment following cyclophosphamide for remission induction.

The MPV was 9.9 \pm 1.1 in SLE patients with nephritis and $10.3 \pm 1.1$ without renal involvement. The levels of MPV were higher in patients without nephritis compared to patients with nephritis. There was no significant difference in MPV between both groups. The correlation was evaluated between MPV and disease activity. We found a correlation between 
MPV and disease activity for SLE patients with renal involvement and without renal involvement $(\mathrm{r}=-$ $0,396, \mathrm{p}=0.04 ; \mathrm{r}=-0.278, \mathrm{p}=0.03$, respectively).

The levels of SLEDAI, sedimentation, and CRP were higher in patients with renal involvement compared to patients without renal involvement. There was a significant difference between both groups for SLEDAI, sedimentation, and CRP. Although MPV level was lower in patients with renal involvement, no statistical differences were found between both groups for MPV (Table 2).

\begin{tabular}{|c|c|c|c|}
\hline \multicolumn{4}{|c|}{$\begin{array}{l}\text { Table 2. The distrbition of disease activity, } \\
\text { sedimantation, CRP, C3, and C4 levels in patients } \\
\text { with lupus nephritis and without lupus nephritis }\end{array}$} \\
\hline & $\begin{array}{l}\text { with lupus } \\
\text { nephritis }\end{array}$ & $\begin{array}{l}\text { without lupus } \\
\text { nephritis }\end{array}$ & $\mathrm{p}$-value \\
\hline Patients (n) & 27 & 58 & \\
\hline Age (mean, year) & $37.3 \pm 12.1$ & $40.6 \pm 9.6$ & 0,13 \\
\hline $\begin{array}{c}\text { Gender } \\
\text { (male/female) }\end{array}$ & $4 / 23$ & $0 / 58$ & 0,003 \\
\hline SLEDAI & $12.7 \pm 7.1$ & $9.6 \pm 5.6$ & 0,02 \\
\hline $\begin{array}{l}\text { Sedimantation } \\
\qquad(\mathrm{mm} / \mathrm{h})\end{array}$ & $47.5 \pm 24.3$ & $30.6 \pm 19.5$ & 0,002 \\
\hline CRP (mg/dl) & $6.1(1.6-20)^{*}$ & $1.7(0.7-5.4)^{*}$ & 0,004 \\
\hline MPV (fL) & $9.9 \pm 1.1$ & $10.3 \pm 1.1$ & 0,09 \\
\hline C3 (g/L) & $86.3 \pm 39.3$ & $109.0 \pm 30.2$ & 0,01 \\
\hline $\mathrm{C4}(\mathrm{g} / \mathrm{L})$ & $16.8 \pm 12.4$ & $24.8 \pm 13.8$ & 0,007 \\
\hline \multicolumn{4}{|c|}{$\begin{array}{l}\text { median (25-75 percentile), SLEDAI: Systemic lupus erythematosus } \\
\text { Disease Activity Index, CRP: C-reactive protein, MPV: mean } \\
\text { platelet volume, C: complement }\end{array}$} \\
\hline
\end{tabular}

\section{DISCUSSION}

In this study, we aimed to evaluate MPV as an easy, cheaper and feasible test in SLE patients with and without renal involvement. In addition, we investigated the correlation between disease activity, inflammation markers and MPV. As a result of our study, MPV levels were lower in SLE patients with renal involvement. No statistically significant difference was found for MPV between SLE patients with and without renal involvement, although there was a significant negative correlation between disease activity and MPV in both groups.

MPV is a laboratory test determined during complete blood count and reflects platelet volume, function, and activation (11). The relationship between MPV and inflammation is not fully understood. It may be associated with the regulation defect of thrombopoiesis affected by the inflammatory process in inflammatory bowel disease (12). MPV may be useful to evaluate disease activation of inflammatory bowel disease, ankylosing spondylitis (AS), and rheumatoid arthritis (RA) $(12,13)$. There have been different results about MPV levels in various rheumatic and inflammatory diseases $(9,14,15)$. For example, MPV levels were higher in patients with systemic sclerosis compared to the control group (16). The levels of MPV in patients with familial Mediterrian fever were found to be increased compared to the control group (17). Increase in MPV levels with treatment has been reported in patients with active AS and RA (13). In another study, the correlation between MPV, inflammatory markers and disease activity in RA patients were reported (18). In this study, it was found decreases in CRP, ESR, and MPV levels after treatment (18). MPV has been reported to decrease in active periods during the course of many SLE (9). In our study, the mean MPV level was $10.2 \pm 1.1 \mathrm{fL}$ and it was increased in SLE patients compared to the healthy control group. The inflammation markers were higher in both SLE patients with and without renal involvement compared to the control group.

The activation of platelets is important in SLE pathogenesis and play an important role in renal involvement. Immune complexes may cause platelet activation due to their connection to FcyRIIA (19). Platelet-derived microparticles produced after platelet activation have been shown to be elevated in lupus nephritis and correlated with proteinuria (19). MPV may be an early indication of lupus activation in juvenile SLE [8]. It has been reported to be a good disease activity marker in patients with $\operatorname{SLE}(8,9$, 20). Lower levels of MPV has been shown in SLE patients with active arthritis compared to inactive patients and healthy group (20). It has been reported that MPV values decreased in adult active SLE patients compared to the inactive disease. We found a lower mean level of MPV in SLE patients with renal involvement than patients without renal involvement. This may be related to the consumption of activated platelets in extravascular inflammation areas (9). 
In contrast, the mean MPV level was reported to be significantly higher in patients with active SLE than inactive patients (21). Increased MPV levels compared to healthy control group and positive correlation between acute phase reactants, disease activity and MPV was found in another study (8). Various results were reported on studies about the relationship between disease activity, inflammation markers and MPV. MPV values were found to be negatively correlated with SLEDAI in active SLE patients, but not correlated with CRP, ESR, and complement levels (22). However, a positive correlation was reported between ESR and SLEDAI $(15,22)$. MPV and NLR may be useful in determining activation and exacerbation of SLE nephritis.

Renal involvement affects prognosis and causes morbidity and mortality in SLE patients. In a study by Yavuz $\mathrm{S}$ et al, no significant relationship was found between MPV and lupus nephritis class [8]. Higher MPV levels were reported in patients with renal involvement compared to patients without renal involvement. There have been statistically differences between both groups (23). There was a negative correlation between MPV and disease activity in SLE patients with renal involvement in our study. Increases levels of MPV has been shown in active SLE patients with renal involvement as a poster presentation (24). However, there is no comprehensive study to determine the relationship between MPV and lupus nephritis. The limitation of our study is that the nature of this study was the retrospective and we were not able to evaluate the changes in parameters such as MPV or inflammation markers after treatment.

Consequently, MPV is negatively correlated with disease activity in lupus patients with renal involvement and without renal involvement. Although MPV levels decrease with disease activity in SLE patients with renal involvement, no significant difference was found between nephritis and non-nephritis group. MPV may be helpful to assess disease activity and organ-involvement but the knowledge about long-term results about this topic is limited.
Conflict of Interest: All authors declare that no conflict of interest.

\section{REFERENCES}

1. Kiriakidou M, Cotton D, Taichman D, Williams S. Systemic lupus erythematosus. Ann Intern Med 2013;159:ITC4-1. doi: 10.7326/0003-4819-159-7201310010-01004

2. Gurevitz SL, Snyder JA, Wessel EK, Frey J, Williamson BA. Systemic lupus erythematosus: a review of the disease and treatment options. Consult Pharm 2013;28:110-121. doi: 10.4140/TCP.n.2013.110

3. Danila MI, Pons-Estel GJ, Zhang J, Vilá LM, Reveille JD, Alarcón GS. Renal damage is the most important predictor of mortality within the damage index: data from LUMINA LXIV, a multiethnic US cohort. Rheumatology (Oxford) 2009;48:542-545. doi: 10.1093/rheumatology/kep012

4. Mahajan SK, Ordóñez NG, Feitelson PJ, Lim VS, Spargo BH, Katz AI. Lupus nephropathy without clinical renal involvement. Medicine (Baltimore) 1977;56:493.

5. Weening JJ, D'Agati VD, Schwartz MM, et al. The classification of glomerulonephritis in systemic lupus erythematosus revisited. J Am Soc Nephrol 2004;15:241-250.

6. Mosca M,Tani C, Aringer M, et al. European League Against Rheumatism recommendations for monitoring patients with systemic lupus erythematosus in clinical practice and in observational studies. Ann Rheum Dis 2010;69:1269-1274. doi: 10.1136/ard.2009.117200

7. Liang MH, Socher SA, Larson MG, Schur PH. Reliability and validity of six systems for the clinical assessment of disease activity in systemic lupus erythematosus. Arthritis Rheum 1989;32:11071118.

8. Yavuz S, Ece A. Mean platelet volume as an indicator of disease activity in juvenile SLE. Clin Rheumatol 2014;33:637-641. doi: 10.1007/s10067014-2540-3

9. Delgado-García G, Galarza-Delgado DÁ, Colunga-Pedraza I. et al. Mean platelet volume is decreased in adults with active lupus disease. Rev 
Bras Reumatol Engl Ed 2016;56:504-508. doi: 10.1016/j.rbre.2016.03.003

10. Petri M, Orbai AM, Alarcón GS, et al. Derivation and validation of the Systemic Lupus International Collaborating Clinics classification criteria for systemic lupus erythematosus. Arthritis Rheum 2012;64:2677-2686. doi: 10.1002/art.34473.

11. Bath PM, Butterworth RJ. Platelet size: measurement, physiology and vascular disease. Blood Coagul Fibrinolysis 1996;7:157-161.

12. Kapsoritakis AN, Koukourakis MI, Sfiridaki A, et al. Mean platelet volume: a useful marker of inflammatory bowel disease activity. Am J Gastroenterol. 2001;96:776-781. doi: 10.1111/j.1572-0241.2001.03621.x

13. Kisacik B, Tufan A, Kalyoncu U, et al. Mean platelet volume (MPV) as an inflammatory marker in ankylosing spondylitis and rheumatoid arthritis. Joint Bone Spine 2008;75:291-294. doi: 10.1016/j.jbspin.2007.06.016

14. Moghimi J, Ghahremanfard F, Salari M, Ghorbani R. Association between mean platelet volume and severity of rheumatoid arthritis. Pan Afr Med J 2017;27:276. doi: 10.11604/pamj.2017.27.276.12228

15. Khan A, Haider I, Ayub M, Khan S. Mean Platelet Volume (MPV) as an indicator of disease activity and severity in lupus. Version 3. F1000 Res 2017;6:126. doi: 10.12688/f1000research.10763.3

16. Soydinc S, Turkbeyler IH, Pehlivan Y, et al. Mean platelet volume seems to be a valuable marker in patients with systemic sclerosis. Inflammation. 2014;37:100-106. doi: 10.1007/s10753-013-9716-x

17. Coban E, Adanir H. Platelet activation in patients with Familial Mediterranean Fever. Platelets. 2008;19:405-408. doi: 10.1080/09537100802187121.

18. Yazici S, Yazici M, Erer B, et al. The platelet indices in patients with rheumatoid arthritis: mean platelet volume reflects disease activity. Platelets. 2010;21:122-125. doi: $10.3109 / 09537100903474373$

19. Scherlinger M, Sisirak V, Richez C, Lazaro E, Duffau P, Blanco P. New Insights on Platelets and
Platelet-Derived Microparticles in Systemic Lupus Erythematosus. Curr Rheumatol Rep 2017;19:48. doi: 10.1007/s11926-017-0678-0

20. Safak S, Uslu AU, Serdal K, Turker T, Soner S, Lutfi A. Association between mean platelet volume levels and inflammation in SLE patients presented with arthritis. Afr Health Sci 2014;14:919924. doi: 10.4314/ahs.v14i4.21

21. Bai M, Xing L, Feng J, Cui C, Huang L, Liang G. Mean Platelet Volume Could Reflect Disease Activity of Adult Patients With Systemic Lupus Erythematosus. Clin Lab 2016;62:1317-1322. doi: 10.7754/Clin.Lab.2015.151134

22. Hartmann LT, Alegretti AP, Machado ABMP. et al. Assessment of Mean Platelet Volume in Patients with Systemic Lupus Erythematosus. Open Rheumatol J 2018;12:129-138. doi: 10.2174/1874312901812010129

23. Ayna AB, Ermurat S, Coşkun BN, Harman H, Pehlivan Y. Neutrophil to Lymphocyte Ratio and Mean Platelet Volume as Inflammatory Indicators in Systemic Lupus Erythematosus Nephritis. Arch Rheumatol 2016;32:21-25. doi: 10.5606/ArchRheumatol.2017.5886

24. Çankaya E, Bilen Y. Mean platelet volume significantly decrease at remission period of SLE patients with renal involvement. Nephrol Dial Transplant 2015;30:439. 